\title{
Metabolic responses of A549 lung cells to cisplatin and radiation exposure studied by $1 \mathrm{H}$ NMR spectroscopy
}

\author{
Ana F Ladeirinha ${ }^{1,2^{*}}$, Inês D Lamego ${ }^{2}$, Ana M Gil ${ }^{2}$, Joana B Melo', Isabel M Carreira', lola F Duarte ${ }^{2}$ \\ From 16th International Charles Heidelberger Symposium on Cancer Research \\ Coimbra, Portugal. 26-28 September 2010
}

This work aims to characterize the dynamic metabolic responses of A549 lung tumor cells exposed to cisplatin (CDDP) and to 6 Gy ionizing radiation over a period of 48h. Control and CDDP/radiation treated cells, in the form of lysed suspensions, were directly analyzed by ${ }^{1} \mathrm{H}$ High Resolution Magic Angle Spinning (HRMAS) NMR spectroscopy $(500 \mathrm{MHz})$ and the changes in their intracellular metabolic profiles assessed by spectral integration and multivariate analysis. In this way, consistent variation patterns could be detected and specific metabolic effects related to drug and/or radiation exposure could be identified. In particular, significant timedependent alterations were found in lipids and cholinecontaining compounds, as well as in low molecular weight metabolites such as some amino acids and nitrogenated bases. The results presented show that ${ }^{1} \mathrm{H}$ NMR spectroscopy is a powerful tool for providing detailed biochemical information about the effects induced on cultured cells by external perturbations, such as a chemotherapy drug and ionizing radiation. In the future, this approach will be applied to lung cancer primary cultures subjected to different treatment regimens.

\section{doi:}

Cite this article as: Ladeirinha et al:: Metabolic responses of A549 lung cells to cisplatin and radiation exposure studied by $1 \mathrm{H}$ NMR spectroscopy. BMC Proceedings 2010 4(Suppl 2):P42.
Author details

${ }^{1}$ Cytogenetics Laboratory and CNC, Faculty of Medicine, University of Coimbra, Coimbra, Portugal. ${ }^{2}$ CICECO, Department of Chemistry, University of Aveiro, Aveiro, Portugal.

Published: 24 September 2010
* Correspondence: analadeirinha@gmail.com

'Cytogenetics Laboratory and CNC, Faculty of Medicine, University of Coimbra, Coimbra, Portugal

Full list of author information is available at the end of the article
Submit your next manuscript to BioMed Central and take full advantage of:

- Convenient online submission

- Thorough peer review

- No space constraints or color figure charges

- Immediate publication on acceptance

- Inclusion in PubMed, CAS, Scopus and Google Scholar

- Research which is freely available for redistribution

Submit your manuscript at www.biomedcentral.com/submit
C Biomed Central 